\title{
Indian Consumer Purchasing Behavior towards Branded Processed Food
}

\author{
M. Vijaya Baskar ${ }^{1} \&$ N. Sundaram ${ }^{2}$ \\ ${ }^{1}$ VIT Business School, VIT University, Vellore, India \\ ${ }^{2}$ SSL Division, VIT University, Vellore, India \\ Correspondence: M. Vijaya Baskar, VIT Business School, VIT University, Vellore, India. E-mail: \\ vijayabaskar.m@vit.ac.in \\ Received: February 12, 2014 Accepted: March 18, $2014 \quad$ Online Published: May 30, 2014 \\ doi:10.5539/ass.v10n11p113 URL: http://dx.doi.org/10.5539/ass.v10n11p113
}

\begin{abstract}
This paper aims to provide comprehensive approach to the consumer purchasing behavior towards branded processed food. There are four broad objectives formulated and subsequently hypothesis was tested to find out the behavior of consumers on purchasing of branded processed food. Variables considered are brand attributes, brand endorsement, brand equity, ethical concerns and demography. We found trust and safety are the two vital parameters drives brand towards consumers. Even though there are other parameters influences consumers but trust and safety creates major influential thing on consumer mind. Age of the consumers are having little impact on purchase of brands over others. Companies can drive their sales philosophy based on trust and safety if they want to establish reliable brand in the long run. This study was carried out in major cities like Chennai, Bangalore, Cochin and Hyderabad in INDIA and may not represent the whole part of the country. Also cities only considered to pick out samples so the result will not reflect the entire population of India. Since not many of the consumer behavior research considered key determinant factors of purchase towards the food purchase. There are multiple variables considered to carry out the study in a comprehensive way-First of its kind in Indian population scenario.
\end{abstract}

Keywords: brands, brand attributes, brand endorsement, brand equity, trust, loyalty and ethical concerns

\section{Introduction}

Indian people food habits are significantly vary from other continents in the universe. Given the diverse group of population and ethnicity it's always a complex issue to find a market in the Indian population. After policy changes in the year 1991, LPG (liberalization, Privatization, Globalization) economic review was adopted and thereafter major changes have took place. Westernization lifestyle got followed up in the major cities across India and people started emulating western country lifestyle (Ali, Kapoor \& Moorthy, 2010). Change in consumer mindset leads to many Multi National corporations find new space to fit their product sales in the Indian people mindset. Due to change over in the lifestyle and evolution of nuclear family, people started preferring packed foods to find ease in cooking. Among $70 \%$ of the Indian family are nuclear in nature and women want to spend less time in cooking. Increase in dual income of the family are also one of the reason to go for purchasing packed branded food products (Kathuria \& Gill, 2013).

There is an growing demand for the ready-to-eat food category and most of the articles defines the type of market it constitutes (Sarin \& Barrows, 2005). The food product will get vary from ready-to-consume to easy-to-cook and consumers prefer any such kind of food, if they are aware of it (Lampila \& La"hteenma"ki, 2007). Even this market growing at the phase of thousand of crores, many MNC's and regional players are eyeing for opportunity in this arena. Changes in lifestyle was considered as major factor in going for packed food purchase as well as growing younger population is also considered as the major factor for this growing trend. Men and Women equal participation in workforce surges demand for food market in India. Convenience and hygienic preference will determine the attitude of consumers in purchasing these types of products (Prasad \& Aryasri, 2008). There are many models tested in determining consumer behavior like Theory of Planned behavior and MBE/OBE models (Choo, Chung \& Pysarchik, 2002). Each models defines consumer behavior from the point of pre-conceived notion. Aaker Model on the other hand, describes about brand identity perceived by the consumer. Here we consider consumer behavior as well as portrays of brand. Combining these two major 
parameters and forming a research framework, have thrown more light on existing theory on consumer behavior.

Branding of generic products will offer consumers a good motive to purchase and its growth surges recently (Prendergast \& Marr, 1997). Consumer behavioral theme is also taken as vital parameter to find out the key determinants of purchasing behavior of consumers towards processed food purchase \& People with innovative mind set go for early purchase of packed foods and tend to be opinion leaders (Ling, Pysarchik \& Choo, 2004). The major studies were concluded that people often not considers brand in food products, because it's considered as low-involvement products and many of the consumer wont devote much time in analyzing or choosing the products. Health conscious people nowadays prefer hygienically packed food products and it constitute a market for premium price (Chakrabarti, 2010). Our analysis was carried out in this context to find out the attitude of Indian consumers towards branded packed food. Brands in consumer behavior with respect to purchase of processed foods become the major part of our work and we found some interesting facts and its discussed at the end of this article.

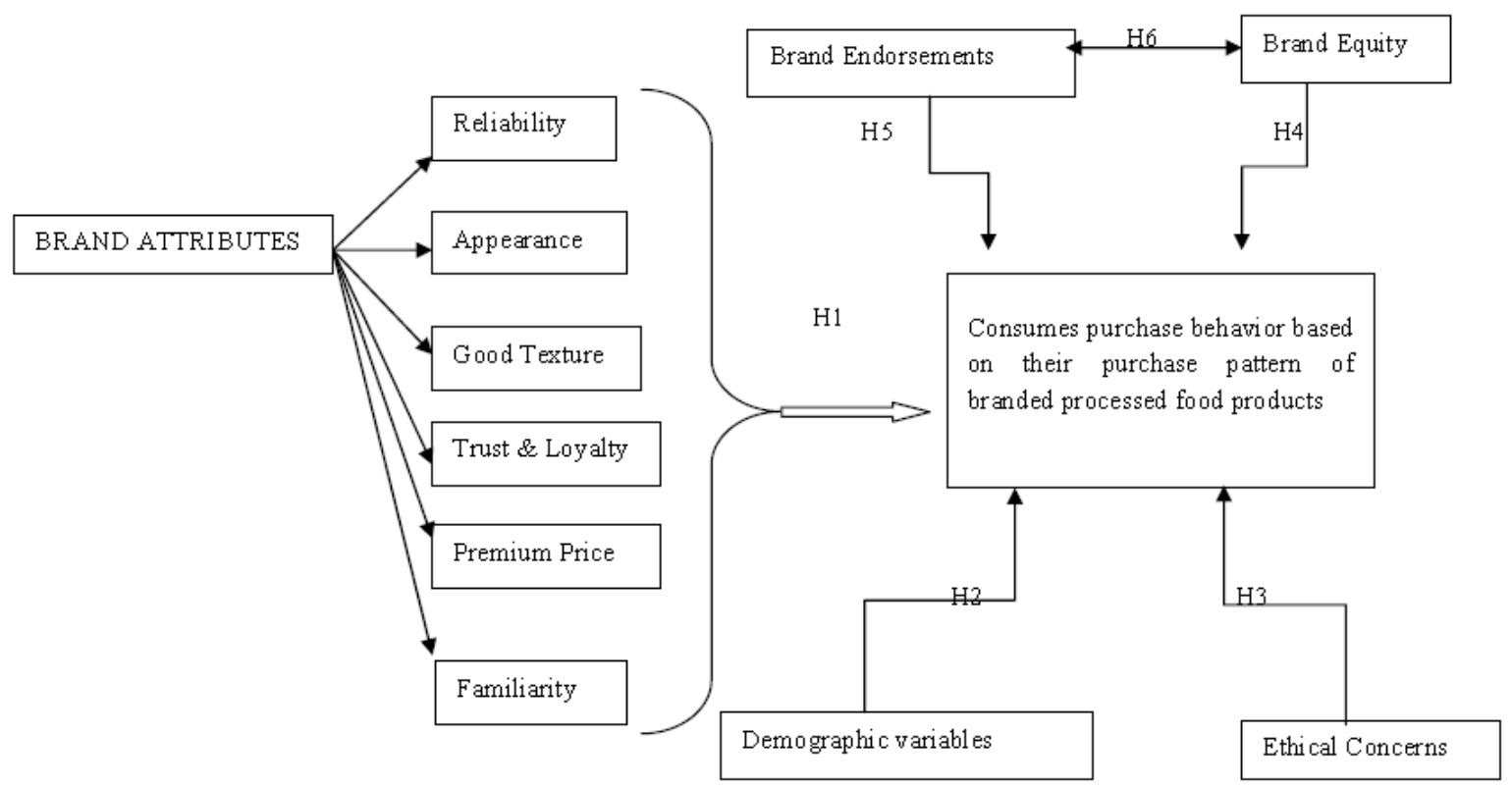

Figure 1. Research framework

\section{Literature Review}

\subsection{Brand Attributes vs Consumer Purchase Behavior}

Aaker \& Keller models describes Brand attributes and its hierarchy (Kumar, 2011). There are some key variables considered to determine brand attributes are quality, appearance, good texture, trust, loyalty, premium price and awareness- (Steptoe, Pollard \& Wardle, 1995). The commonalities in brand often reminds consumer to go for brand and here we tested this in the scenario of food purchase. Brands will simplify choices and associations of brands often pop-ups in consumer mindset and drives them to purchase. There may be one or multiple factors in brand attributes determines purchase decision. In other sense, each consumers are unique and go by their own set of decision making based on their conceived character of brands (Fearne \& Lavelle, 1996). Brands may portrays different things with different consumers and at the end each attributes drives sales. Attitude is also one of the key factor in choosing brands based on the attributes (Foxall \& Bhate, 1992). Even if brand dictates major premium price, people buys the product as it is common in apparels and high-involvement products like cars, we want to test the same in food purchase habit. The vital parameters determines brand attributes are finalized to six and we included all these in our questionnaire, hence we have formulated the hypothesis as follows.

H1: There is a significant association between brand attributes and consumers purchase of brands

\subsection{Demographic Variables vs Consumer Purchase Behavior}

Demography variables will form a significant factor in this current study on consumer behavior. It offers way for sound conclusion on consumer behavior (Ahlgren, Gustafsson \& Hall, 2006). Socio-economic factors determines 
perception of food and purchase activity (Bingol \& Ceylan, 2012). As we pointed out earlier, Indian consumers food habits and purchase patterns are unique in nature so we decided to include demography as one of the variables in consumer behavior. Even major studies in consumer behavior are taken demographic dividends are one of the key determining factors in the study especially when the study is tuned towards commodities. Study carried out on people background will throw more light on behavior patterns and often gives marketers a good insight to position their product. Indian people often provides different opinion under different circumstances and takes decision based on their emotional quotient, rather than usage of the product, but new emerging younger population decides products on rational mind sent. In this scenario considering demography is one of the major variables will makes sense to us. The hypothesis are formulated as follows.

$\mathrm{H} 2$ : There is a significant association between demographic variables and consumers purchase of brands

\subsection{Ethical Concerns vs Consumer Purchase Behavior}

Ethics often not considered as an important variable in purchasing brands, but our literature survey pointed out that, when it comes to food products, people often considers ethics in choosing the product. This point is evident in the case of Patrick De Pelsmacker, Wim Janssens, Ellen Sterck, Caroline Mielants 2005, where ethically labeled coffee is preferred by consumers. Ethics in the other hand testify the emotional content of an individual. Labelling the product like eco and bio-labels is least preferred by consumer when compared with ethical branding of a product. Fair trade label fixed on the product is preferred by many consumer, the results shown. The results are common across different socio-demographic groups. Responsibilities exhibited by companies over environment and people, will trigger positive response of purchase (Anselmsson \& Johansson, 2006). Providing proof of the company responsibility will bring loyal consumers to that product. There is a positive correlation between company ethical practices and consumer response. If the consumer commitment increases, the ethical burden of the company also increases (Story \& Hess, 2010). Labelling is one of the major influential factor in going for purchasing product (Davies \& Wright, 1994). Brands endorsed with trustworthy labels often fits well with purchase behavior of consumers. This proper labeling conveys that particular product is good and edible and in other way adds ethical concerns of consumer (Graham, Harker, Harker \& Marshall Tuck, 1994). Hence we conclude the third hypothesis as follows.

H3: There is a significant association between ethical concerns of consumers and purchase of brands

\subsection{Brand Equity vs Consumer Purchase Behavior}

Brand equity analysed from financial point of view is common in management research, whereas consumer based brand equity also evolved as a concept, along with financial based brand equity. Consumers perception on the product rather than objective indicators forms the core of consumer based brand equity (Chieng \& Lee, 2011) It brings loyalty and drives sales in the long run and consumers find personal attachment with product if brand equity increases. There is a positive correlation inclined between brand equity and consumer response. Brand Equity will also be helpful in extending brands to new horizons and will bring loyal consumers, if positioned in a right way. It also brings down advertisement cost and gives confident to enter into new sector if parent brand positioned properly (Pitta \& Katsanis, 1995). Brand Equity can be studied by the parameters like Brand awareness, brand association, perceived quality, brand trust and brand loyalty. Brand equity is considered as macro term and below it fits all kind of parameters to evaluate such brand capacity and its performance (Kumar, Dash \& Purwar, 2013). Purchase attitude and loyalty determines brand equity performance. Even its tough to quantify brand equity performance, its possible to find empirical evidence to measure the length and breadth of brand equity performance. Trust breeds loyalty and contributes to brand loyalty. It is argued the said two parameters didn't decide on brand equity but performs mediating role (Delgado-Ballester \& Munuera-Alema'n, 2005). Based on this literature aspects, we formulated fourth hypothesis as follows.

H4: There is a significant association between brand equity and consumers purchase of brands

\subsection{Brand Endorsements vs Consumer Purchase Behavior}

Brands endorsed by different previous achievements have weightage in driving sales. For Example "Kodak-The official film of the 1996 Olympics", "Ford-The best selling truck in America" is the way products are exhibited to consumer to stimulate purchase. There is a positive sign towards brand endorsements and purchase behavior (Dean, 1999). Naming of country-of-origin in the products strives consumer purchase behavior. Foreign labels are well received as trustable brands when compare with local origin (Kinra, 2006). Brand image is constituted by brand endorsements. Different endorsements suitable to that product will find positive influence on purchase intention. Brand endorsements in food products, will give positive influence to purchase. This instill confidence in the mind set of consumers. Even if its endorsed by origin and other ethnic popularity, will find trigger in sales 
of that product (Guercini \& Ranfagni, 2013). Brand Endorsements find useful if the company is going for merger $\&$ acquisition and guarantee minimum success factor in driving sales. Brand Endorsements may be to give different meaning to the product and in turn it have to instill confidence in the mind set of consumer to go for purchase. For the food products to be considered, brand endorsements will bring faith to consumers and act as trigger point for selling. Food packets endorsed by like, free from chemicals, organically produced, fair-trade label, No child labour used, Hand picked, Free from bacteria, laboratory certification are all form the good endorsements to brand. Endorsements on brand need to be tested in Indian context so we formulated fifth hypothesis as follows.

H5: There is an association between Brand Endorsements and Consumers purchase of brands

\subsection{Brand Endorsement vs Brand Equity}

Even both the variables constitute different activity on consumer behavior, comparing these two will make aware of how one variables contributes to another variable or vice versa. Brand endorsement will act as sub-factor when compare with brand equity. The macro term defined here is brand equity. Brand endorsement will sow trust and breeds loyalty in the consumer mind and in turn improves brand equity performance. brand equity and trust are consistently the most important antecedents to both behavioral and attitudinal forms of customer loyalty (Taylor, Celuch \& Goodwin, 2004). There is an hierarchical comparison between brand association with brand equity in Aaker's brand equity Model. Brand equity and associations promote brand extension in a positive way and reduces advertisement expenditure of a company (Pryor \& Brodie, 1998). In the case of mergers brand equity and endorsement will contribute growth of a company. If the brands are national and private brand, then each brand used to contribute either companies towards growth (Vaidyanathan, 2000). Brand is a major factor and can be achieved by establishing relationship between endorsement, loyalty and value. Brand will become great asset if the merger of variables keep in momentum with the consumer preference (Wood, 2000). By considering the relationships between brand endorsement and brand equity, we formulated sixth hypothesis as follows

H6: There is an association between brand endorsements and brand equity

\section{Methods}

Sampling and data collection:-Each of the four shoppers coming out of the malls were targeted and encouraged participants by offering them a compliment on completion of questionnaire. There were 124 samples collected but due to inadequacy we have consolidated in to 102 samples. The table below shows the demographic profiles of the participants. Major cities in south India were concentrated to collect samples. Cities like Chennai, Bangalore, Hyderabad and cochin malls were surveyed for this research.

Table 1. Demographic details of respondents

\begin{tabular}{llll}
\hline$*$ & Category & Number & Percentage \\
\hline Gender & Male & 49 & 48.03 \\
\multirow{4}{*}{ Age } & Female & 53 & 51.96 \\
& $18-24$ & 22 & 21.56 \\
& $25-34$ & 48 & 47.05 \\
\multirow{3}{*}{ Marital Status } & $35-44$ & 30 & 29.41 \\
\multirow{3}{*}{ Final Education } & 44 & 02 & 2.04 \\
& Married & 76 & 74.50 \\
& Un Married & 26 & 25.49 \\
House Hold Income & Professional & 42 & 41.17 \\
& Non-Professional & 52 & 50.98 \\
\multirow{3}{*}{ Family Type } & Others & 8 & 7.84 \\
& $<$ Rs,20,000.00 & 16 & 15.68 \\
& Rs,20,000.00 to Rs,50,000.00 & 70 & 68.62 \\
& $>$ Rs,50,000.00 & 16 & 15.68 \\
& Nuclear Family & 84 & 82.35 \\
& Joint Family & 18 & 17.64 \\
\hline
\end{tabular}




\subsection{Data Analysis}

Analysis was done using SPSS V20. We presumed Chi-Square \& ANAVOA is the best method to be employed since the hypothesis want to find association between different variables. All the questions are provided with rating scales like, Strongly agree to Strongly Disagree .Even the analysis may look simpler but we have to bring clarity on our comparison so we deployed only this statistical tool to keep our paper precise in every sense.

\section{Results and Discussion}

\subsection{Result I: Brand Attribute vs Consumer Purchase Behaviour}

H1: There is a significant association between brand attributes and consumers purchase of brands

Brand attributes are tested with the following questions

(5-Strongly agree, 4-Agree, 3-Neutral, 2-Disagree, 1-Strongly Disagree)

1) Brands in processed food packets is preferable

2) Brands in processed food packets is unnecessary

Table 2. Test statistics

\begin{tabular}{lll}
\hline & BAtt1 & BAtt2 \\
\hline Chi-Square & $23.391^{\mathrm{a}}$ & $27.261^{\mathrm{b}}$ \\
df & 3 & 4 \\
Asymp. Sig. & .072 & .003 \\
\hline
\end{tabular}

The above results shows the significance level is .072 so it reject null hypothesis in the first case. For the second question, the significance level is .003 so it accepts null hypothesis. Our survey tells that brands in processed food packets is preferable.

Consumer purchase behavior are tested with the following four questions

1) I like brand because it simplify my choice among other products

2) I choose brand because of trust and value for money

3) I choose brand because of safety it offers

Upon the four above questions, the central theme of our paper revolves and was put to test in survey. Even the above questions are rated from strongly agree to strongly disagree.

Table 3.

\begin{tabular}{lll}
\hline & Mean square & Sig \\
\hline Behavioral Theme 1 (Between groups) & 1.444 & .007 \\
Behavioral Theme 1 (within groups) & .309 & \\
Behavioral Theme 2 (Between groups) & 3.878 & .022 \\
Behavioral Theme 2 (within groups) & 1.085 & \\
Behavioral Theme 3 (Between groups) & 1.417 & .108 \\
Behavioral Theme 3 (within groups) & .659 & \\
\hline
\end{tabular}

Brands offers safety as we can infer from the above result. The respondent who chooses brands are necessary in packed food also chooses brand offers safety. Safety will become the prime important for the consumer to purchase brands. Hence, the hypothesis 1 is accepted that what brand attributes portrayed is welcomed by consumers.

\subsection{Result II: Demographic Variables vs Consumer Purchase Behavior}

$\mathrm{H} 2$ : There is a significant association between demographic variables and consumers purchase of brands

We have taken three important parameters as demographic variables like age, gender and family type. Food 
consumption and purchase is normally based on the family size and lifestyle. Gender difference will also have impact on choosing brands.

Table 4. Test statistics

\begin{tabular}{|c|c|c|c|c|c|}
\hline & & & Age & Gender & Family_Type \\
\hline Chi-Square & & & $19.217^{\mathrm{a}}$ & $.348^{\mathrm{c}}$ & $5.565^{\mathrm{c}}$ \\
\hline df & & & 4 & 1 & 1 \\
\hline Asymp. Sig. & & & .001 & .555 & .018 \\
\hline \multirow{3}{*}{ Monte Carlo Sig. } & Sig. & & $.001^{\mathrm{b}}$ & $.667^{\mathrm{b}}$ & $.029^{\mathrm{b}}$ \\
\hline & \multirow{2}{*}{ 99\% Confidence Interval } & Lower Bound & .000 & .655 & .024 \\
\hline & & Upper Bound & .002 & .679 & .033 \\
\hline
\end{tabular}

Table 5.

\begin{tabular}{lll}
\hline Age & Mean Square & Significance \\
\hline Behavioral Theme 1 (Between groups) & 2.619 & .047 \\
Behavioral Theme 1 (Within groups) & .987 & .032 \\
Behavioral Theme2 (Between groups) & 3.186 & \\
Behavioral Theme 2 (Within groups) & 1.085 & .282 \\
Behavioral Theme3 (Between groups) & .905 & \\
Behavioral Theme 3 (Within groups) & .690 & Significance \\
\hline Gender & Mean Square & .298 \\
\hline Behavioral Theme 1 (Between groups) & 1.254 & .849 \\
Behavioral Theme 1 (Within groups) & 1.130 & \\
Behavioral Theme2 (Between groups) & .048 & .707 \\
Behavioral Theme 2 (Within groups) & 1.299 & \\
Behavioral Theme3 (Between groups) & .104 & Significance \\
Behavioral Theme 3 (Within groups) & .723 & .226 \\
\hline Family Type (Joint / Nuclear) & Mean Square & .591 \\
\hline Behavioral Theme 1 (Between groups) & 1.688 & \\
Behavioral Theme 1 (Within groups) & 1.120 & .387 \\
Behavioral Theme2 (Between groups) & .379 & \\
Behavioral Theme 2 (Within groups) & 1.292 & \\
Behavioral Theme3 (Between groups) & .545 & .713 \\
Behavioral Theme 3 (Within groups) & & \\
\hline
\end{tabular}

Based on the philosophy of null hypothesis, we conclude that age will have association with the behavior whereas the gender and family type doesn't have any impact on purchase behavior. Age correlates with buying behavior states that people choose brand because it simplify options and repose trust on purchase.

\subsection{Result III: Ethical Concerns vs Consumer Purchase Behavior}

H3: There is a significant association between ethical concerns of consumers and purchase of brands

Ethical concerns of consumers are tested by the following two questions posted to them

1) Animal friendly products are necessary to purchase brands

2) Welfare schemes mentioned in the pack inspires to purchase 
The above two questions are tested with Consumer behavior of three questions mentioned earlier and result as follows

Table 6.

\begin{tabular}{lll}
\hline Ethical Concern 1 & Mean Square & Significance \\
\hline Behavioral Theme 1 (Between groups) & .681 & .679 \\
Behavioral Theme 1 (Within groups) & 1.176 & \\
Behavioral Theme2 (Between groups) & 3.415 & .022 \\
Behavioral Theme 2 (Within groups) & 1.062 & .123 \\
Behavioral Theme3 (Between groups) & 1.266 & \\
Behavioral Theme 3 (Within groups) & .655 & Significance \\
\hline Ethical Concern 2 & Mean Square & .959 \\
\hline Behavioral Theme 1 (Between groups) & .192 & .969 \\
Behavioral Theme 1 (Within groups) & 1.224 & \\
Behavioral Theme2 (Between groups) & .185 & .656 \\
Behavioral Theme 2 (Within groups) & 1.377 & \\
Behavioral Theme3 (Between groups) & .450 & .734 \\
Behavioral Theme 3 (Within groups) & & \\
\hline
\end{tabular}

Animal friendly products are preferred by group of peoples, whereas the ethical concerns of the brands doesn't have any impact on purchase. Consumers are not inclined to give importance to the brand claims on the product.

\subsection{Result IV: Brand Equity vs Consumer Purchase Behavior}

H4: There is a significant association between brand equity and consumers purchase of brands

Brand Equity are tested by the following two parameters

1) I purchase brand because of long term association with that brand

2) I have positive feelings for the brand I choose

The above two questions are tested against regular consumer behavior attitude and the results are as follows

Table 7.

\begin{tabular}{lll}
\hline Brand Equity 1 & Mean Square & Significance \\
\hline Behavioral Theme 1 (Between groups) & 1.085 & .004 \\
Behavioral Theme 1 (Within groups) & 1.137 & \\
Behavioral Theme2 (Between groups) & .222 & .000 \\
Behavioral Theme 2 (Within groups) & 1.374 & .000 \\
Behavioral Theme3 (Between groups) & .724 & \\
Behavioral Theme 3 (Within groups) & .708 & Significance \\
\hline Brand Equity 2 & Mean Square & .002 \\
\hline Behavioral Theme 1 (Between groups) & .144 & .000 \\
Behavioral Theme 1 (Within groups) & 1.23 & \\
Behavioral Theme2 (Between groups) & .165 & .001 \\
Behavioral Theme 2 (Within groups) & 1.267 & \\
Behavioral Theme3 (Between groups) & .246 & \\
Behavioral Theme 3 (Within groups) & .458 & \\
\hline
\end{tabular}


The level of significance are all .000 so it accepts null hypothesis. Brand Equity will have direct impact on purchase behavior of consumers.

\subsection{Result V: Brand Endorsements Vs Consumers Purchase of Brands}

H5: There is an association between Brand Endorsements and Consumers purchase of brands

The theme of brand endorsements are based on the following parameters and tested against purchase attitude

1) Symbol, logo, trademark are necessary to choose brands

2) Quality certificates like ISO,ISI are mandatory to choose brands

Table 8.

\begin{tabular}{lll}
\hline Brand Endorsement 1 & Mean Square & Significance \\
\hline Behavioral Theme 1 (Between groups) & 2.073 & .114 \\
Behavioral Theme 1 (Within groups) & 1.041 & \\
Behavioral Theme2 (Between groups) & 2.168 & .141 \\
Behavioral Theme 2 (Within groups) & 1.184 & .263 \\
Behavioral Theme 3 (Between groups) & .938 & \\
Behavioral Theme 3 (Within groups) & .687 & Significance \\
\hline Brand Endorsement 2 & Mean Square & .499 \\
\hline Behavioral Theme 1 (Between groups) & .922 & .080 \\
Behavioral Theme 1 (Within groups) & 1.147 & \\
Behavioral Theme2 (Between groups) & 2.801 & .073 \\
Behavioral Theme 2 (Within groups) & 1.162 & \\
Behavioral Theme3 (Between groups) & 1.608 & .645 \\
Behavioral Theme 3 (Within groups) & & \\
\hline
\end{tabular}

Based on the above shown results we can infer that brand endorsements doesn't have any impact on purchase attitude of consumer.

\subsection{Result VI: Brand Endorsements vs Brand Equity}

H6: There is an association between brand endorsements and brand equity

The null hypothesis framed is rejected by the results. It shows there is no significant relationship between brand endorsements and brand equity. People choose brand equity based on loyalty and trust and long term relationship. Brand endorsements didn't improve brand equity as such.

\section{Discussion}

This study taken various characteristics of consumers in a consolidated way and analyzed why consumer choose branded food products. The key driven factor which emerged out was trust and safety. In other words we say most of the consumers are risk aversion people and they don't want to take courage step in choosing food products-especially going for unbranded. Brands are preferred for different purpose and each segment dictates different things in consumer mind but when it comes to food purchase it is noted that most of the consumer are viewing brand in the perspective of safety and trust.

\section{Conclusion}

In our study we find out that the consumer purchase brands mostly on the parameters of trust and safety. These two parameters builds long term association with the brands. Even though there are other factors people considers while choosing brands, trust and safety are become the vital parameters to purchase brands. Brand endorsements, brand ethical concerns, brand attributes are have little impact on purchase intention. Hence, we conclude brands offer safety and trust from the consumer point of view.

\section{Limitations of the Study}

This study revolves around the main cities of southern India and it may not reflect the entire population opinion. 
Brands are analyzed from the purchase point of view rather than on actual usage of the products. In the further study, these limitations can be overcome by stretching the study further into other dimensions.

\section{References}

Ahlgren, M. K., Gustafsson, I.-B., \& Hall, G. (2006). Buyers' demands for ready meals - influenced by gender and who will eat them. Journal of food service.

Ali, J., Kapoor, S., \& Moorthy, J. (2010). Buying behaviour of consumers for food products in an emerging economy. British food journal. http://dx.doi.org/10.1108/00070701011018806

Anselmsson, J., Ulf Johansson, S. (2007). Corporate social responsibility and the positioning of grocery brands -An exploratory study of retailer and manufacturer brands at point of purchase. International journal of retail \& distribution management. http://dx.doi.org/10.1108/09590550710820702

Chakrabarti, S. (2010). Factors influencing organic food purchase in India - expert survey insights. British Food Journal. http://dx.doi.org/10.1108/00070701011067497

Choo, H. J., Chung, J.-E., \& Pysarchik, D. T. (2004). Antecedents to new food product purchasing behavior among innovator groups in India. European journal of Marketing. http://dx.doi.org/10.1108/03090560410529240

Davies, M. A. P., \& Wright, L. T. (1994). The Importance of Labelling Examined in Food Marketing. European Journal of Marketing. http://dx.doi.org/10.1108/03090569410055283

Dean, D. H. (1999). Brand Endorsement, Popularity, and Event Sponsorship as Advertising cues affecting consumer Pre-Purchase Attitudes. Journal of Advertising. http://dx.doi.org/10.1080/00913367.1999.10673585

Delgado-Ballester, E., \& Munuera-Alema'n, J. L. (2005). Does brand trust matter to brand equity? Journal of Product \& Brand Management. http://dx.doi.org/10.1108/10610420510601058

Fearne, A., \& Lavelle, D. (1996). Perceptions of food "quality" and the power of marketing communication: results of consumer research on a branded-egg concept. Journal of product and Brand Management. http://dx.doi.org/10.1108/10610429610119423

Foxall, G. R., \& Bhate, S. (1992). Cognitive style and personal Involvement as Explicators of Innovative purchasing of Healthy food brands. European journal of Marketing.

Graham, P., Harker, D., Harker, M., \& Tuck, M. (1994). Branding Food Endorsement Programs-The National Heart Foundation of Australia. Journal of Product and Brand Management. http://dx.doi.org/10.1108/10610429410073110

Guercini, S., \& Ranfagni, S. (2013). Integrating country-of-origin image and brand image in corporate rebranding: The case of China. Marketing Intelligence \& Planning. http://dx.doi.org/10.1108/MIP-04-2013-0058

Kathuria, L. M., \& Gill, P. (2013). Purchase of branded commodity food products: empirical evidence from India. British Food Journal. http://dx.doi.org/10.1108/BFJ-08-2011-0209

Kinra, N. (2006). The effect of country-of-origin on foreign brand names in the Indian market. Marketing Intelligence \& Planning. http://dx.doi.org/10.1108/02634500610641534

Koç, B., \& Ceylan, M. (2012). The effects of social-economic status of consumers on purchasing, behaving and attitude to food products-Case study of Van, Turkey. British Food Journal. http://dx.doi.org/10.1108/00070701211230006

Kumar, M. (2011). The Impact of 'Brand equity' determinants on consumers' purchase decisions. A case study of the processed food sector in the national capital region of India. Journal of Business and Retail Management research.

Kumar, R. S., Dash, S., \& Purwar, P. C. (2013). The nature and antecedents of brand equity and its dimensions. Marketing Intelligence and Planning. http://dx.doi.org/10.1108/02634501311312044

Lampila, P., \& La“hteenma“ki, L. (2007). Consumers' attitudes towards high pressure freezing of food. British food journal. http://dx.doi.org/10.1108/00070700710821368

Ling, S.-S., Pysarchik, D. T., \& Choo, H. J. (2004). Adopters of new food products in India. Marketing Intelligence \& Planning. http://dx.doi.org/10.1108/02634500410542743 
Pelsmacker, P. D., Janssens, W., Sterckx, E., \& Mielants, C. (2005). Consumer preferences for the marketing of ethically labeled coffee. International Marketing Review. http://dx.doi.org/10.1108/02651330510624363

Pitta, D. A., \& Katsanis, L. P. (1995). Understanding brand equity for successful brand extension. Journal of consumer marketing. http://dx.doi.org/10.1108/07363769510095306

Prasad, C. J. S., \& Aryasri, A. R. (2008). Study of Customer Relationship Marketing Practices in Organised Retailing in Food and Grocery Sector in India: An Empirical Analysis. The journal of Business Perspective. http://dx.doi.org/10.1177/097226290801200404

Prendergast, G. P., \& Marr, N. E. (1997). Generic products: Who buys them and how do they perform relative to each other? European Journal of marketing. http://dx.doi.org/10.1108/03090569710157070

Pryor, K., \& Brodie, R. J. (1998). How advertising slogans can prime evaluations of brand extensions: Further empirical Results. Journal of Product and brand Management. http://dx.doi.org/10.1108/10610429810244666

Sarin, S., \& Barrows, C. (2005). An Examination of Current Food and Beverage Trends in India and an Assessment of Potential Demand for Luxury Food and Beverage Products: Implications for Managers. Journal of services research (Special issue).

Steptoe, A., Pollard, T. M., \& Ardle, J. (1995). Development of a Measure of the Motives Underlying the Selection of Food: The Food Choice Questionnaire. Journal of Appetite. http://dx.doi.org/10.1006/appe.1995.0061

Story, J., \& Hess, J. (2010). Ethical brand management: customer relationships and ethical duties. Journal of product and brand management. http://dx.doi.org/10.1108/10610421011059568

Taylor, S. A., Celuch, K., \& Goodwin, S. (2004). The importance of brand equity to customer loyalty. Journal of Product and brand management. http://dx.doi.org/10.1108/10610420410546934

Vaidyanathan, R. (2000). Strategic brand alliances: Implications of ingredient branding for national and private label brands. Journal of product and brand management. http://dx.doi.org/10.1108/10610420010344013

Wood, L. (2000). Brands and brand equity: definition and management. MCB university press.

Yew Leh, C. F., \& Lee, G. C. (2011). Customer-Based Brand Equity: A Literature Review. Journal of Arts science \& commerce.

\section{Copyrights}

Copyright for this article is retained by the author(s), with first publication rights granted to the journal.

This is an open-access article distributed under the terms and conditions of the Creative Commons Attribution license (http://creativecommons.org/licenses/by/3.0/). 